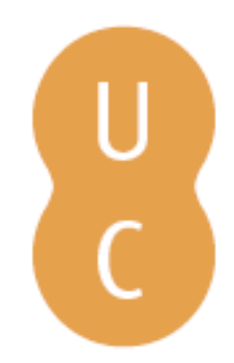

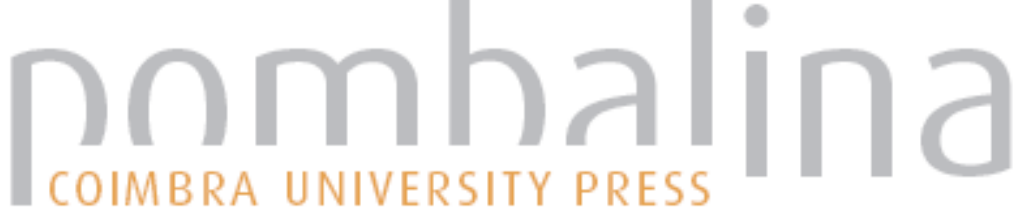

\section{Virtus Ipsa: o retrato literário nos Annales de Tácito}

Autor(es): $\quad$ Pimentel, Maria Cristina de Castro-Maia de Sousa

Publicado por: Imprensa da Universidade de Coimbra

URL

persistente:

URI:http://hdl.handle.net/10316.2/32564

DOI:

DOI:http://dx.doi.org/10.14195/978-989-26-0442-8_5

Accessed : $\quad$ 26-Apr-2023 13:08:57

A navegação consulta e descarregamento dos títulos inseridos nas Bibliotecas Digitais UC Digitalis, UC Pombalina e UC Impactum, pressupõem a aceitação plena e sem reservas dos Termos e Condições de Uso destas Bibliotecas Digitais, disponíveis em https://digitalis.uc.pt/pt-pt/termos.

Conforme exposto nos referidos Termos e Condições de Uso, o descarregamento de títulos de acesso restrito requer uma licença válida de autorização devendo o utilizador aceder ao(s) documento(s) a partir de um endereço de IP da instituição detentora da supramencionada licença.

Ao utilizador é apenas permitido o descarregamento para uso pessoal, pelo que o emprego do(s) título(s) descarregado(s) para outro fim, designadamente comercial, carece de autorização do respetivo autor ou editor da obra.

Na medida em que todas as obras da UC Digitalis se encontram protegidas pelo Código do Direito de Autor e Direitos Conexos e demais legislação aplicável, toda a cópia, parcial ou total, deste documento, nos casos em que é legalmente admitida, deverá conter ou fazer-se acompanhar por este aviso.

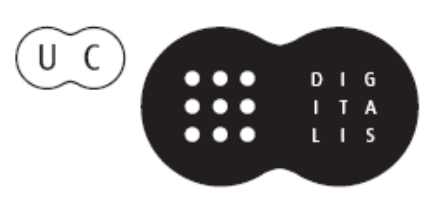


Aurelio Pérez Jiménez, Joșé Ribeiro Ferreira

e Maria do Céu Fialho

(COORdinadores)

\section{Adminiftri Principum.}

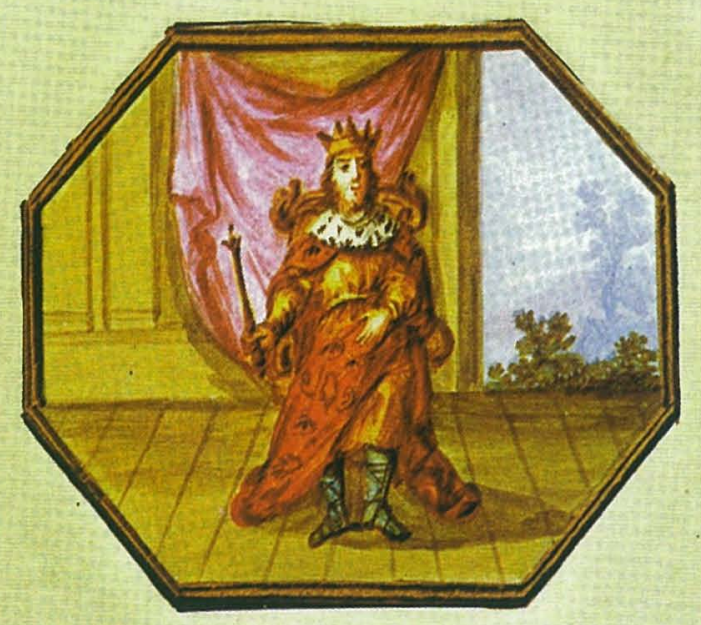

\section{EMBLEM A LIV.}

En tibi plura gerit, quàm lumina prabuit Argos Rex; Aures totidem, quin totidemó, manus. Hec opus Imperio, fidis fupplenda Minijtris, Regi bi funt aures: lumina clara, manus.

\section{- Retrato e a Biografia como estratégia de teorização política}

IMPRENSA DA UNIVERSIDADE DE COIMBRA

Universidad de MálaGa 
(Página deixada propositadamente em branco) 
Aurelio Pérez Jiménez

José RIBEIRo FERREIRA

Maria do Céu Fialho

O RETRATO LITERARIO E A BIOGRAFIA COMO ESTRATÉGIA

\section{DE}

TEORIZACCÃO POLITICA

IMPRENSA DA UNIVERSIDADE DE COIMBRA

UnIVERSIDAD DE MÁlaGa

2004 
Obra publicada com a colaboração de:

Centro de Estudos Clássicos e Humanísticos (Universidade de Coimbra)

International Plutarch Society

Primera edição, Junho de 2004

(c) IMPRENSA DA UnIVERSIDADE DE COIMBRA

(c) Área de Filología Griega. Universidad de Málaga

Coordenação editorial:

Imprensa da Universidade de Coimbra

Área de Filología Griega de la UMA

ISBN: 972-8704-25-9 (PORTUGAL)

ISBN: 84-608-0166-7 (ESPANHA)

Depósito Legal: MA-1420

Impresso em Espanha

Execução gráfica:

IMAGRAF IMPRESORES, S.A.

c/ Nabucco 14

29006 Málaga

Tfno. 952328597

Página de rosto:

"Dos Princepes Transùmptos verdadeiros": Francisco António Novaes Campos, Principe perfeito. Emblemas de D. Joâo de Solórzano. Edição fac-similada do manuscrito da Biblioteca Nacional do Rio de Janeiro oferecido ao Príncipe D. João em 1790 (Prefácio, introdução, comentário e índices por Maria Helena de Teves Costa Ureña Prieto), Instituto de Cultura e Língua Portuguesa, Lisboa, 1985, Emblema LIV, p. 114. 


\title{
VIRTUS IPSA: O RETRATO LITERÁRIO NOS ANNALES DE TÁCITO
}

\author{
Maria Cristina de Castro-Maia \\ de Sousa Pimentel \\ Universidade de Lisboa
}

Muito se tem escrito sobre a obra de Tácito, o seu estilo, o seu conceito de história, o significado político do que escreve e, segundo alguns, do que insinua. Certos passos revelam-se particularmente felizes para, numa leitura atenta, reflectirmos sobre a forma como tais vectores se revelam, de modo a um tempo magistral e belíssimo.

Escolhemos, para a nossa análise, o retrato de Trásea Peto, figura ímpar na galeria de homens e mulheres que Tácito chama à criação da sua história. Estóico e senador, torna-se personagem de eleição na reflexão de Tácito sobre as relações entre o senado e o princeps e na análise das causas que conduziram ao fracasso do principado tal como foi entendido pelos sucessores de Augusto durante todo o séc. I. Advirtamos desde já que não nos parece nem que Tácito pretenda fazer uma história de desgraças e tirania para realçar a época de uma nova libertas inaugurada com Nerva e Trajano, nem que pretenda outra coisa senão entender os desvios e atentados a um ideal em que ele, senador e Romano, manifestamente acreditava, qual era o das reais possibilidades de um regime em que senado e princeps harmoniosamente dividissem o poder e se concertassem para o bem de Roma e do mundo.

Tácito defende o principado e, talvez por isso, nem sempre parece estar de acordo com certas atitudes de desafio ou mesmo subversão, ainda que elas se dirijam contra um mau princeps, como fora o caso de Nero. No caso da contestação individual, sem deixar de admirar a coragem e a firmeza de alguns, não deixa de notar a inutilidade e ineficácia de certos comportamentos que apenas serviam para des-

A. Pérez Jiménez, J. Ribeiro Ferreira, Maria do Céu Fialho (edd), O retrato literário e a biografia como estratégia de teorização política, Coimbra-Málaga, 2004, pp. 65-82. 
graçar quem os assumia e para tornar mais violento o tirano no poder. Em casos de contestação mais ampla, como a conjura de 65 , que o historiador mostra ter sido planeada por um grupo heterogéneo, sem programa comum nem sequer, relativamente à maioria dos conspiradores, motivações muito nobres ${ }^{1}$, também parece não ver nela mais do que o reflexo do descontentamento geral suscitado por Nero, e entende-a sem dúvida como mais um momento em que não foi dado nenhum passo decisivo para a reconciliação entre principatus e libertas.

Trásea Peto, e também Bárea Sorano, estóico e senador como ele, 'fecham' de certo modo os Annales, já que é deles que se ocupa a parte final dos livros que chegaram até nós. Ora, como alguns têm feito notar, os estóicos constituem um grupo cuja atitude relativamente ao regime instituído e ao princeps no poder mais parece intrigar Tácito e, em certos casos, suscitar mesmo o seu desacordo.

Sabemos que os estóicos, ao contrário dos epicuristas, defendiam a participação na vida política, que, perante a instauração do principado, alguns houve que se distinguiram pela sua oposição republicana, entendendo o novo regime político como incompatível com a libertas, e que por essa contestação pagaram com a vida ou dela abdicaram, como fez Catão de Útica. Sabemos também que, com o passar dos anos - e o longo principado de Augusto e o equilíbrio, pelo menos aparente, entre o seu poder pessoal e o do senado, que a posteridade baptizou como diarquia, para tal contribuiu decisivamente - sabemos, dizia, que a posição dos estóicos se foi cristalizando na aceitação de que nada havia de nefasto no regime que concentrava o poder nas mãos de um só homem, desde que esse homem praticasse a uirtus e dela desse exemplo aos seus súbditos ${ }^{2}$, o que implicava naturalmente respeitar a dignidade dos outros, governar com justiça, reconhecer a importância do contributo livre e empenhado que o senado podia e devia dar a Roma.

Num quadro muito geral, é esse entendimento que justifica o comportamento de Séneca junto de Nero, aplicação prática do princípio de que, se não for possível depositar o poder nas mãos de um sapiens, então deve estar o sapiens junto do governante para lhe instruir os passos no caminho da uirtus, prolongando-se essa colaboração e magistério enquanto for útil e benéfica, mas também enquanto, e apenas enquanto, a dignidade do próprio sapiens não se encontrar ameaçada ${ }^{3}$. E é tam-

${ }^{1}$ Cf. Annales XV 49.

${ }^{2}$ Como expõe Séneca no De Clementia.

${ }^{3}$ Cf. Séneca, Ep. 22, 8. 
bém esse o entendimento que subjaz ao percurso político e à orientação de vida de personagens como Trásea Peto e Bárea Sorano.

Tácito, ao invés, ele que melhor que ninguém devia conhecer, por tê-la assumido sob os Flávios, uma atitude distinta perante o principado - a da colaboração competente em que a fides e a cura reipublicae, e não uma fé política, constituem o único e verdadeiro caminho para assegurar a libertas - parece entrever por vezes no comportamento dos estóicos alguma irresponsabilidade que a nada conduz e uma certa vontade de gloria pessoal sempre que assumem o papel de protagonistas, isolados e de extremados gestos, de um processo de contestação que os transforma em heróis de um grupo restrito de oposição, mas heróis trágicos, sobre quem inevitavelmente se abaterá a desgraça, de certo modo buscada pelos seus próprios actos.

O caso de Peto torna-se, assim, exemplar para o historiador reflectir e analisar todos esses vectores. Num percurso de elaborado desenho literário, em que os processos de criação se multiplicam em paralelo com a riqueza das personagens e a densidade das situações, Tácito mostra-nos uma figura única, que ele procura compreender e sinceramente admira, ainda que não deixe de apor, aqui e além, a marca da sua dúvida ou desacordo perante algumas das suas atitudes e escolhas. E fá-lo, em última análise, porque não escreve uma história em que os bons são $100 \%$ bons e os maus radicalmente maus, numa contenda que se salda em desgraça para os bons, se os maus estão no poder, mas porque entende a complexidade e a riqueza da alma humana e dos seus sentimentos, porque conhece e retrata o ser humano nas suas motivações e dúvidas, no seu agir e pensar, porque reflecte sobre o passado para entender o presente. É nesse sentido que Trásea Peto adquire nos Annales o estatuto de exemplo e de testemunho, o dos seres humanos que tudo arriscam - e por isso tudo perdem - por coerência e rectidão de princípios, por corajosa atitude que os leva a não engolir a honra e a não vergar a dignidade, vendendo-a ou colaborando com o poder mais violento e a prepotência mais mesquinha. Nesse aspecto, $o$ que retoma o sentido etimológico da palavra, Trásea surge, no texto de Tácito, como verdadeiro 'mártir', digno de ser lembrado e admirado, como o historiador manifestamente se empenhou em conseguir.

Vejamos, pois, de que forma e por que processos nos apresenta Tácito essa figura. Centrar-nos-emos nas circunstâncias que lhe talham a desgraça e no momento concreto da morte, relato que ocupa os capítulos 21 e 34-35 dos Annales. No entanto, há que observar brevemente as informações que Tácito dá anteriormente sobre a personagem, pois é esse o processo que prepara e justifica o clímax da desgraça. 
Trásea aparece-nos pela primeira vez nos Annales numa intervenção no senado sobre aquilo que Tácito considera uulgarissimum senatus consultum (XIII 49, 1) e que declara só referir porque Trásea o rebateu e, com isso, forneceu materiem obtrectatoribus arguendae sententiae ${ }^{4}$. Assim, sabemos desde logo que ele tem detractores, inimigos à espreita que aproveitam todos os seus movimentos e palavras para tentarem incriminá-lo e fazê-lo cair em desgraça. Também concluímos que Trásea não hesita em tomar atitudes melindrosas ou polémicas. É que a decisão contra a qual se pronunciou consistia na autorização dada aos Siracusanos de ultrapassarem o número de gladiadores estabelecido para os munera. A oposição a tal medida era impopular pois, como se sabe, quanto maior o aparato dos ludi, maior era a alegria da populaça e maior se tornava a influência de quem os dava. Tácito alinha ( $(2)$, em discurso indirecto livre, os argumentos do contra-ataque dos opositores de Peto, baseado na incoerência do seu comportamento, pois, apregoando a necessidade de uma libertas senatoria, ocupava-se de ninharias (tam leuia). Perguntam-lhe porque não dava ele a sua opinião de bello aut pace, de uectigalibus et legibus e sobre todas as questões que de facto importavan a Roma. Argumentam com a liberdade que se goza no senado, onde todos os patres têm o direito de exprimir a sua opinião e de submetê-la à discussão e deliberação. Atiram-lhe (§ 3) perguntas capciosas: é essa a única emendatio que the apraz fazer, impedir que em Siracusa se dêem jogos com maior prodigalidade? Seria Trásea capaz de governar melhor que Nero? E concluem: quem deixava passar, sem intervir, as grandes questões romanas, com muito mais razão deveria manter-se calado quando se tratasse de inania.

Os argumentos dos detractores dão-nos o retrato do comportamento de Trásea no ano de 58, seis anos antes da sua desgraça e morte: vai ao senado, mas abstém-se de intervir em questões de fundo, ou porque não concorda com o que aí se discute e resolve, ou porque considera inútil o seu contributo em matéria previamente decidida e manobrada segundo a vontade do princeps e seus sequazes.

Mas Tácito dá voz (§ 4) à resposta de Trásea a essas acusações, registando que ele se justifica não perante os detractores mas perante os amigos que lhe pedem a razão do seu procedimento, num apontamento que pode bem traduzir a independência de Trásea, a sua verticalidade $\mathrm{e}$ o desprezo que vota às críticas que lhe dirigem, e às quais nem responde nem se verga por temor. É aos amici que ele considera dever respostas. A estes diz que não é por desconhecer as circunstâncias do momento que ele propõe acusações que apresenta a Nero, visando Trásea. 
consulta daquele género, mas justamente porque quer dar aos senadores a honra de mostrarem que não fecharão os olhos aos assuntos importantes aqueles que, como é o caso deles, se preocupam também com leuissima, casos de pouca monta. Por esta resposta, Tácito fornece-nos mais um traço do retrato de Peto: a sua luta passa por devolver ao senado a dignidade que perdeu ou the tiraram, por fazer ver aos patres que devem ter um papel actuante e isento, não permitindo nem que os dirijam nas decisões a tomar em assuntos de importância, nem que considerem normal ou desejável alinhar na estratégia do rebanho que tudo acata e contra nada se rebela.

A segunda vez (XIV 12,1) em que Tácito fala de Trásea refere-se a Abril de 59, momento em que, acoitando-se em Nápoles logo após o assassínio de Agripina, Nero envia ao senado uma mensagem, segundo parece escrita por Séneca, em que conta a sua versão dos acontecimentos: como se sabe, acusava a mãe de tentar matá-lo e de, descobertas as suas intenções, se ter suicidado. Tácito demora-se no que considera um mirum certamen entre os proceres, as figuras gradas de Roma, evidentemente os patres, para mais e melhor adularem o princeps e mais e mais gravemente atentarem contra a própria dignidade. Em crescendo de ignomínia, decretam-se supplicationes, decide-se que as Quinquátrias, as festas em honra de Minerva durante as quais se descobrira a suposta conspiração, seriam celebradas anualmente com jogos, que uma estátua em ouro da deusa seria colocada na cúria ao lado da do princeps, por fim que o dies natalis de Agripina passaria a contar-se inter nefastos.

Do grupo de senadores, atolados em abjecção, competindo em desonra, emerge Trásea, de quem Tácito diz que se remetera ao hábito de deixar passar silentio uel breui adsensu as anteriores adulações - expressão que engloba sem dúvida não apenas as que naquela sessão foram propostas mas todas as de anteriores reuniões mas que, a dado momento, decerto o que corresponde à maldição do dia de aniversário de Agripina, se levantou e saiu do senado. Trásea, que aguentou a sessão como pôde, sem alinhar nem pela adulação nem pelo falso júbilo de que todos davam mostras, não suportou o crescendo de aviltamento a que os senadores se prestavam e, para não ser conivente, abandonou a cúria.

É um gesto heróico e digno que Tácito comenta, em passo que tem provocado os mais desencontrados comentários. Diz ele: ac sibi causam periculi fecit, ceteris libertatis initium non praebuit. Embora registe a coragem da atitude, Tácito não pode senão considerar que tal gesto serviu tão-só para atrair sobre Trásea a desgraça que dele se aproximava em avassalador galope, sem simultaneamente ter representado mais que um movimento de contestação individual, que em nada contribuiu para abrir aos outros o caminho da libertas. $\mathrm{O}$ historiador parece ter aqui como base para a sua, não direi cen- 
sura, mas reserva, a opinião de que é dentro do sistema que se defronta o que ele tem de mal e que, em conjugação de esforços, num corpo uno e solidário como o senado, se devem criar as condições para corrigir os desvios e repor a libertas e a justiça.

Registe-se, todavia, que Trásea continua a ir ao senado, e continuará a fazê-lo, em clara demonstração de que, como estóico que era, entendia ser seu dever participar na vida política e também dar aos outros o exemplo da sua conduta ${ }^{5}$, se já não pela acção ou pelas palavras, pelo menos com o silêncio, pelo menos enquanto a infâmia não fosse insustentável, momento em que havia que abandonar a vida pública: foi isso que, pouco tempo depois, Séneca fez; foi isso que Trásea acabou também por fazer.

Na terceira vez em que Tácito foca (XIV 48-49) a figura de Trásea Peto, estamos já no ano 62 e o pretor Antístio Sosiano é acusado por Cossuciano Capitão nome que há-de ser uma peça-chave na preparação da desgraça de Peto - do crime de maiestas, por ter composto probrosa carmina contra o princeps e, ainda por cima, tê-los divulgado durante um banquete muito frequentado, em casa de Ostório Sabino. Foi essa a primeira vez em que, sob o principado de Nero, tal lei foi reposta em vigor, o que dá a medida da escalada do terror e da crueldade ${ }^{6}$. Proposta a pena de morte more maiorum, isto é, ser vergastado até à morte, Trásea surge (48, 3 ) em desacordo com todos os que se manifestam a favor. Tácito mostra-o de novo sozinho contra a corrente avassaladora dos que, por medo ou por interesse, colaboram com a tirania e apoiam a injustiça. É ele quem contrapropõe ${ }^{7}$ a confiscação dos bens e a relegatio numa ilha, de forma a que Antístio pague o ultraje com o sofrimento da sua existência, de preferência prolongada, e seja simultaneamente o exemplo máximo da aplicação da clementia. Em resumo, Trásea manifestou-se contra a pena de morte e mostrou ao senado que não devia ser ele a decretar tal punição contra um dos seus, desvendando o alcance do endurecimento dos castigos e apontando

Cf. Séneca, De Tranquillitate animi 3.

6 Pensava-se ainda que se preparava não a perda de Antístio mas sim a glória de Nero que, decretada a pena, sem dúvida interviria com o seu veto tribunício para lhe comutar a pena de morte e apregoar a sua clementia. Mas não foi isso que aconteceu: Ostório Sabino declarou que nada ouvira, mas houve testemunhas que garantiram o fundamento da acusação.

Tácito dá as linhas gerais do que apresenta como tendo sido o discurso que pronunciou: começou, estrategicamente, com o louvor de Nero e a censura vivíssima de Antístio, mas demonstrou que tal castigo, ainda que merecido, jamais deveria ser decretado pelo senado, egregio sub principe e sem o constrangimento de nenhuma obrigação, pois o carnifex e o laqueus há muito tinham sido abolidos e havia penas estabelecidas na lei que se podiam aplicar ao caso. 
uma condenação mais suave e mais consentânea com a apregoada clementia de Nero. Mas Trásea mete a mão num vespeiro, o dos que o querem abater, tanto mais que, como Tácito diz a abrir o cap. 49, libertas Thraseae seruitium aliorum rupit, numa afirmação que contrasta com o juízo que emitira em XIV 12, 1 sobre a inutilidade do seu gesto ao abandonar o senado. A oposição entre a libertas de Trásea e o seruitium de todos os outros, sublinhada pelo paralelismo da construção, confere uma nota sublime de grandeza à apreciação que é feita do seu comportamento.

No momento da votação, só uns poucos não seguiram a opinião de Peto ${ }^{8}$. No entanto, os grilhões da servidão geral que ele quebrou com a sua independência viriam a transformar-se nas cadeias e nós que o foram amarrando e estrangulando, num cerco cada vez mais apertado que terminaria com a morte. Cossuciano saberá esperar o momento de tramar a perdição de Trásea. O princeps, posto ao corrente do sucedido, hesitou entre a vergonha e a cólera, mas viu-se obrigado a aceitar a decisão, não sem antes fazer sentir os limites que o senado transpusera e sem esconder a offensio que the faziam não dando a devida punição à gravíssima afronta que sofrera.

O senado nem assim reviu a sua decisão, dando mostras, pelo menos uma vez e seguindo o rumo de Trásea, de que lhe restava honra e dignidade, embora para tal firmeza Tácito dê razões não totalmente elogiosas. Quanto a Peto, diz que ele não mudou o seu parecer sueta firmitudine animi et ne gloria intercideret $(49,3)$, num processo em que a uariatio do estilo consagra a sua habitual firmitudo animi mas deixa pairar ainda alguma reserva quanto ao desejo de gloria que motivaria, ou pelo menos participaria da motivação, das suas atitudes.

Novo salto no tempo, desta vez até ao fim de 62, quando é julgado o cretense Cláudio Timarco, a quem, entre outros crimes, acusam de ter ultrajado o senado com a sua arrogância. As palavras de Trásea surgem em discurso directo (XV 20,2) e Tácito mostra que ele tentou usar a circunstância ad bonum publicum ${ }^{9}$; mas o que mais peso teve na sua intervenção foi ter aproveitado (XV 21) para comentar e criticar a política de Roma relativamente às províncias, que declarou deverem ser governadas aequabilius atque constantius. Um assentimento geral $(22,1)$ acolheu a

Entre eles, não deixa Tácito de o referir, estava Vitélio, o futuro imperador, adulatione promptissimus, mas de pauidum ingenium (cf. 49, 1).

9

Uma vez mais sem deixar de censurar o acusado, Trásea propõe que ele seja banido, mas mostra que as leges egregiae e os exempla honesta são muitas vezes inspiradas aos homens de bem ex delictis aliorum, sugerindo então que se tome uma decisão digna da fides e da constantia romanas. 
proposta de Peto $^{10}$. Estamos agora longe das ninharias de que o acusaram de se ocupar: aqui trata-se de macropolítica e de censura às orientações seguidas por Nero.

No princípio de 63, Popeia Sabina deu à luz uma menina, e Nero entregou-se ao mais desenfreado júbilo pelo nascimento da filha. Como seria de esperar, todo o senado se precipitou ${ }^{11}$ para Âncio, onde o parto acontecera. Pelo que Tácito escreve depreendemos que Trásea estava entre os que foram saudar o princeps, pois diz que lhe foi vedado o acesso ao imperador. Isto é: foi excluído da presença de Nero, impedido sequer de se associar às manifestações de homenagem do corpo senatorial.

É a desgraça que se abate, inexorável, sobre ele, e Tácito garante que ele suportou a afronta immoto animo, atitude de estóico, embora essa contumelia fosse claro prenúncio da iminência da condenação à morte. Em seguida, o historiador acrescenta uma informação que merece comentário. Pouco tempo depois espalhou-se uma notícia: Nero gabava-se de se ter reconciliado com Trásea e fê-lo junto de Séneca; e este terá felicitado Nero pelo sucedido. As informações, secas, permitem por si só algumas conclusões. É Nero quem põe a correr o suposto entendimento com Trásea, facto de que se gaba. Assim, naturalmente, o que é divulgado é que Peto se vergou ao princeps, retractando-se do seu comportamento de independência e desafiante censura. Nem de outra forma poderia ser, pois quem se considerava ofendido era Nero e o princeps jamais tomaria a iniciativa de se reconciliar com um súbdito seu, mesmo que houvesse razão para isso. Por outro lado, ao divulgar essa reconciliação, Nero forja uma atmosfera de entendimento e perdão que o mostra clemens e dele desvia a suspeita de qualquer intenção de perseguir ou matar Peto. Assim, o odioso de tais atitudes recairá sobre outros, não sobre ele. Por fim, na atitude de Séneca, já afastado de toda a influência e caído em desgraça, já na curva descendente que terminará na acusação e na morte, vislumbra-se a independência e a grandeza de espírito que lhe permite congratular o princeps, e não Trásea, por essa suposta reconciliação. O desafio é claro: o filósofo, evidentemente, sabe ou adivinha que não é verdade, Trásea não se justificou perante o imperador; ainda assim, e sem abertamente o desmentir, simula acreditar, mas felicita Nero pelo

Elaborou-se um senatusconsultum que proibia às assembleias provinciais a proposta de qualquer gratiarum actio, expressão de votos de louvor e agradecimento aos governadores, como forma de reprimir a ambitio. Mas os cônsules não o homologaram, alegando que o assunto não se encontrava na ordem do dia da sessão do senado.

11 É essa pressa em prestar vassalagem que o ablativo absoluto omni senatu ... effuso (XV $23,4)$ denuncia. 
facto, o que sugere que é ele, Nero, quem tem a ganhar com esse entendimento e não o contrário, que é o princeps quem tem a aprender com o estóico a uirtus de que ele é exemplo. Séneca deve ainda ter percebido a intenção do imperador ao escolhê-lo para se gabar da inventada reconciliação: é o modo de insinuar-lhe que faça o mesmo, que se retracte e o bajule, opróbrio a que obviamente Séneca não se submete.

Tácito é muito claro na conclusão que tira acerca das consequências do que acabou de narrar e, em geral, de todas as atitudes que os dois estóicos, Séneca e Trásea, foram tendo para com Nero e o sistema, e diz: unde gloria egregiis uiris et pericula gliscebant (XV 23, 4). A gloria surge aqui por completo despojada de crítica: nela se associam dois uiri que se dizem egregii, e mais do que nunca é pertinente o sentido etimológico tanto do substantivo como do adjectivo. Um e outro, uiri porque detentores de uirtus, egregii porque se distinguiram do grex, o rebanho apático que se deixa conduzir, que nasceu para obedecer e aguardar, sem brilho nem coragem, o momento de ser abatido. No destino, que Tácito expressamente associa, de Séneca e Trásea, perto do fim, gloria e pericula aumentam de forma directamente proporcional. Um e outro sabem-no, e não recuam nem temem.

Antes do relato do fim de ambos, Tácito volta a referir-se uma única vez a Séneca ${ }^{12}$. Trásea, esse, voltamos a encontrá-lo quando, meses depois da morte do filósofo, se prepara a cabala que o conduzirá à morte. E, então, é a Bárea Sorano que o seu destino surge associado.

$\mathrm{O}$ início de XVI 21 é impressionante: a aliteração em $\underline{\mathrm{t}}$ das primeiras palavras, a insistência nos verbos do campo lexical da violência (trucidatis; exscindere; interfecto), a metonímia transformada em antonomásia de uirtutem ipsam, que se identifica com Trásea e Sorano, sobre os quais, em dramático zoom, se centra a objectiva do historiador, a classificação das causas que movem Nero como não pertencentes ao domínio do racional mas sim do emocional e subjectivo (concupiuit; infensus), o de um ódio antigo (olim) cujas vítimas surgem irmanadas na desdita (utrisque), tudo aponta para um cúmulo de abuso do poder (ad prostremum), para o maior dos crimes que Nero está prestes a perpetrar. Mas o olhar de Tácito fixa-se

12 Quando, após o incêndio de Roma e perante o autêntico saque a que Nero se entregou para financiar a sua megalomania, o filósofo pediu - e não conseguiu - autorização para se retirar definitivamente, sendo pouco depois alvo de uma tentativa de envenenamento (XV 45). Depois, vem o relato esperado: todo o processo da descoberta da conspiração de Pisão, a denúncia do envolvimento de Séneca, a sua morte gloriosa e digna (XV 56 ss.). 
em Trásea, isolado na evocação dos motivos particulares da sua queda em desgraça (et accedentibus causis in Thraseam), que vai esmiuçar uma a uma, recapitulando e resumindo circunstâncias que tratou anteriormente (ut memoraui) e acrescentando outras: porque (quod) saíra do senado aquando da deliberação após a morte de Agripina (cf. XIV 12, 1); porque (quodque) nos Iuuenalia, os jogos criados por Nero para se exibir, não mostrara grande entusiasmo e porque (quia), falta que aumenta a anterior por lhe estar relacionada, Trásea, em ludi na sua cidade natal, Patauium, habitu tragico cecinerat, facto grave não porque ia contra os costumes e a dignidade de um senador romano ${ }^{13}$, mas porque Nero não tolerava rivais que pudessem turvar-lhe a glória de artista ${ }^{14}$. Isto sabe-o o leitor e não é preciso explicitá$10^{15}$. Depois também (quoque) porque, quando o pretor Antístio incorria na pena capital, censuit obtinuitque, falou e arrastou outros com ele para uma decisão mais branda (mitiora) que desautorizava o imperador e ignorava a ofensa que lhe fora feita (cf. XIV 48-49). E ainda (et) porque, quando se prestavam honras divinas a Popeia - acabada de morrer, nas condições suspeitas que Tácito evocou (cf. XVI 6, 1) - sponte absens, funeri non interfuerit. Trata-se de um novo dado, o de que Peto não deu, com a sua presença, aval a mais uma das ignomínias de Nero. E agiu assim por sua livre vontade (sponte), não porque o princeps o tenha excluído da cerimónia, como fez com outros ${ }^{16}$, ou como fizera com ele aquando do nascimento da filha ${ }^{17}$.

No $\S 3$, quae funciona como termo recolector das razões, as accedentes causae atrás enumeradas. São elas que invoca o delator Cossuciano, agente da perdição de

13 Que provocava a indignação dos que se guiavam pelo mos maiorum e reagiriam como perante a atitude de Calpúrnio Pisão, caput da conspiração de 65 (cf. XV 65, em que se diz que Súbrio Flavo decidira pôr Séneca, e não Pisão, à frente dos destinos de Roma, pois jamais aceitaria substituir um citaredo, Nero, por alguém que tragico ornatu canebat).

Cf. XVI 4-5, que é por si só bastante para documentar a afirmação.

O paralelo é evidente: Pisão tragico ornatu canebat; Trásea habitu tragico cecinerat, mas as razões que assistiam a Flavo e a Nero são diametralmente opostas.

Como Cássio Longino, que ganhara o desfavor de Nero (cf. XIII 41, 4) e viu, como primeiro sinal da desgraça que o atingira, ser-lhe proibido pelo imperador estar presente nos funerais de Popeia. Cássio deveu ainda a animosidade do princeps aos antepassados ilustres, entre eles o assassino de César, cujos ideais republicanos seguiria, preparando a queda do regime. Foi condenado ao exílio na Sardenha, mas regressou perdoado no tempo de Vespasiano.

Cf. XV 23, 4. Tácito assume como perfeitamente coerente esta ausência voluntária de Trásea das exéquias de Popeia, dada a sua atitude, que poderíamos classificar de insurreição ou desobediência civil, à data do acontecimento. 
Trásea, que já conhecíamos de XIV 48-49. É ele que, provando que não perdoara a Peto a derrota sofrida no senado ${ }^{18}$, dá forma à acusação e transforma os sentimentos negativos de Nero para com Trásea em razões concretas para a condenação; é ele que lhas lembra insistentemente, como marca o aspecto verbal do imperfeito sinebat, acicatando-lhe o ódio e despertando-lhe o desejo de, uma vez mais, matar, cruel e injustamente, desta vez um dos dois mais insignes uiri de Roma. Repare-se que a 'focalização' em Cossuciano veio sendo insinuada, num desdobramento entre o que o princeps sentia por Trásea e as razões concretas que não é ele, Nero, a enumerar, mas sim outro que lhas recorda. Ora, esse memorando é feito por ordem cronológica. Não nos parece, todavia, ser esse o único motivo de estarem em gradação. Nas primeiras circunstâncias evocadas, Trásea ainda está presente, no senado e nos Iuuenalia, embora marque a sua censura ou desagrado com o silêncio ou a indiferença. No processo do pretor, já se faz notar uma atitude de desautorização da vontade de Nero que, ainda por cima, levou muitos senadores a agirem do mesmo modo. A última circunstância representa o completo desrespeito e desprezo, manifestados publicamente pela ausência. Cossuciano sabe o que faz. E Tácito não deixa de dizer porque o faz, num processo que, como se se tratasse de um jogo de contrastes, mais ilumina a inocência e a estatura moral de Trásea. Cossuciano tem mau carácter (ad flagitia praeceps) ${ }^{19}$, o que é a razão geral, e é iniquus Thraseae, a razão particular, a que o move a agir e a 'construir' o processo contra ele junto de Nero. Porquê? Porque Trásea (quod), e o historiador desvenda agora o que realmente motiva a acusação, com a sua auctoritas, o fizera perder o processo de repetundis que lhe tinha sido movido pelos delegados dos Cilícios, aos quais Trásea dera ajuda legal ${ }^{20}$. Tácito omite aqui a referência ao processo de maiestas contra o

18 Veja-se no entanto que, habilmente, a alusão a este processo não inclui a referência ao envolvimento e interesse de Cossuciano na condenação. Sugerindo-se, pelo discurso indirecto livre, que é Cossuciano quem apresenta as razões a Nero, não convém àquele dar a ideia de que vinga ultrajes pessoais, percutindo ao invés a tecla que mais eficaz se afigura: mostrar ao imperador as afrontas que Trásea cometeu contra o princeps.

19 Todas as informações que Tácito já dera sobre Cossuciano confirmam o recorte negativo da personagem. Veja-se que, quando acusou o pretor Antístio, se diz que o fez logo que recuperou a dignidade senatorial precibus Tigellini, soceri sui, o que é manifestamente uma má recomendação, não só pela ligação familiar a tal tratante, como porque recuperou o seu estatuto senatorial não por direito, mas por influências pessoais. Surge, assim, também como todos os 'convertidos', campeão nas perseguições, ansioso de 'mostrar trabalho', neste caso odioso a reposição da lex maiestatis.

20 Cf. XIII 33, 2. Aí, Trásea não é referido mas, na boca dos Cilícios, Cossuciano era maculosus foedusque, e usurpador, na província, dos mesmos direitos de que abusara em Roma. 
pretor Antístio, pois o próprio Cossuciano o lembrou a Nero, e a conclusão que o leitor tira é evidente: $o$ acusador age por vingança ${ }^{21}$.

Nos capítulos seguintes, numa escalada dramática, Tácito passa em revista as restantes acusações que são feitas a Trásea (22), as que se imputam a Sorano (23), o decisivo sinal de ruptura que Nero manifesta a Trásea, e o último acto de sereno e corajoso desafio deste para com o princeps, que convoca o senado para o julgar (24), o momento em que os amigos de Trásea se dividem no conselho sobre se deve ou não defender-se perante o senado $(25 ; 26)$; finalmente, o processo de Trásea (2729) e o de Sorano, no qual é também arrastada sua jovem filha Servília (30-33), numa alternância que não corresponde apenas à ordem cronológica e às necessidades de uariatio da composição, mas sublinha a união trágica destas figuras grandiosas, que despertam um sentimento de admiração a que Tácito não é alheio.

Por fim, nos capítulos 34 e 35, acompanhamos os derradeiros momentos de Trásea. Pouco antes de saber a sentença, ele está nos seus jardins, o que demonstra serena impassibilidade perante a decisão que outros tomavam sobre o seu destino. É a atitude do sapiens estóico: Trásea sabe que não pode adiar a morte, se o seu momento for aquele, e espera-a aequo animo, embora pressinta decerto a inevitabilidade da condenação, pois sabe o tempo em que vive e o princeps que o governa. O momento em que a notícia chega é também carregado de significado: uesperascente iam die. $\mathrm{O}$ dia cai, a luz desaparece, aproxima-se a noite. Sem forçar os subentendidos, a luz que está prestes a desaparecer é a da uirtus ipsa, a de Trásea e também de Sorano e Servília. A noite que se adensa é a das trevas da crueldade e intolerância: é a escuridão que se faz numa Roma dominada pelas forças da maldade, pelos homens que traem e se vendem. De certo modo, é como se um tempo chegasse ao fim, o tempo em que havia gente como Trásea e Sorano, mas também como Séneca e outros cuja morte ou atitude heróica Tácito lembra nos Annales, particularmente nos Livros XV e XVI ${ }^{22}$, num recorte trágico que não esquece figuras femininas como Servília, filha de Sorano, ou Paulina, mulher de Séneca. Tácito segue aqui sem dúvida o género literário dos exitus illustrium uirorum, que tanta divulgação tinha na época ${ }^{23}$, - - não será de esque-

21 Nem outra coisa seria de esperar de alguém que, por um processo comum a Tácito no desenho das personagens, sempre deu mostras dos mais baixos sentimentos. V. XI 6, 3; XIII 42, 1 ss.; XIV 17, 5.

Veja-se, por ex., o caso de Lúcio Antístio Vétere, sua filha e sogra (XVI 10 ss.).

23

Dele são representantes dois amigos de Plínio-o-Moço (cf. Ep. V 5; VIII 12): Gaio Fânio, que escreveu três livros sobre a história de personalidades exiladas ou executadas por Nero, e Titínio Capitão, que se ocupou de outras executadas por Domiciano. 
cer que um dos jovens estóicos a quem Trásea deixou o testemunho, Aruleno Rústico, que se ofereceu para opor o seu veto tribunício à condenação de Trásea, tendo este recusado para não o fazer cair também em desgraça ${ }^{24}$, escreveu uma uita dele, que Tácito decerto conhecia, e que motivou a condenação do seu autor no tempo de Domiciano $^{25}$. Mas a imagem que o historiador expressamente se empenha em desenhar é a do filósofo estóico na plenitude da sua uirtus, exemplo de sapiens que acolhe a morte não como um mal, mas como um indiferente.

Trásea tinha junto dele um numeroso grupo de inlustres uiri feminaeque, sem dúvida aqueles que se identificavam com o seu ideário e que, como ele, não temiam as consequências dos seus actos de desafio à prepotência, que era o que faziam ao segui-lo e privarem com ele. Falava em particular com Demétrio, filósofo cínico ${ }^{26}$, e com ele discutia de natura animae et dissociatione spiritus corporisque, assunto sem dúvida adequado, quer a ambas as doutrinas, a estóica de Peto e a cínica de Demétrio, quer ao momento que todos sabiam iminente. Mas tal alusão aproxima de imediato a situação descrita, numa espécie de 'jogo de espelhos', da morte de outros sapientes, em especial aqueles que eram mais admirados pelos estóicos, Sócrates e Catão de Útica, de quem, aliás, Trásea escrevera uma $u i t a^{27}$, mas ainda de Séneca. Se Sócrates também bebeu a cicuta ao entardecer e antes debateu com os amigos as questões que Platão registou no Fédon, se Catão de Útica leu o Fédon antes de se suicidar, é com o suicídio de Séneca, bem presente na memória do leitor ${ }^{28}$, que Tácito vai pôr em paralelo a morte de Trásea, numa identificação que os iguala na coerência de vida levada às mais funestas consequências e consagrada na morte segundo os preceitos estóicos. Não podemos comparar aqui todos os aspectos, inclusivamente linguísticos, em que as duas narrativas expressamente se aproximam; de igual modo nos pareceria fecundo um outro cotejo, desta vez pelo já referido 'jogo dos contrastes', aquele que resulta em enaltecimento das mortes de Séneca e Trásea por oposição ao relato da morte de Lucano, o estóico que não sabe sê-lo até ao último suspiro e ao maior sofrimento, que fraqueja nos seus princípios e convicções e trai, denunciando a própria mãe e os amigos, para tentar salvar a vida ${ }^{29}$, e ao relato do suicídio de

24

25

26

27

28

29

Cf. XVI 26, 4.

Agric. 2, 1; 45, 2.

Amigo de Séneca, como seria de esperar (cf. Benef. VII 8; 11).

Plutarco, Cato minor 25, 1;37, 2.

Cf. XV 60-64.

Negando o que seu tio pouco tempo antes escrevera: Non omni pretio uita emenda est (Ep. 70, 7). 
Petrónio, modelo do comportamento epicurista ${ }^{30}$.

Depois de ter tomado conhecimento da decisão do senado, Trásea vê-se rodeado de amigos, flentes queritantesque ( $(2)$. Todos os que estão com ele deixam-se tomar pelo desgosto e a aflição, e é ele que tem de os chamar à realidade, exortando-os a que abandonem de imediato a sua casa, para que não ligassem os seus destinos cum sorte damnati: uir sapiens, ele preocupa-se, nos momentos que antecedem a morte, com a segurança dos outros. A mulher, Árria, quer seguir o marido na morte, também ela apresentada como exemplo de uma estirpe de mulheres estóicas que partilham a vida e a morte com os maridos, que como eles enfrentam a opressão com determinação e coragem. Árria segue ainda o modelo de sua mãe, Arria Maior, mulher de Cecina Peto, que, para dar ânimo ao marido, condenado à morte por Cláudio, cravou no peito o punhal que em seguida lhe deu, pronunciando as palavras que Plínio-o-Moço celebrizou (Ep. III 16, 6: Paete, non dolet).

Trásea, porém, não aceita o sacrifício da mulher e dá-lhe razões para continuar viva: ela deve ser o subsidium unicum, o único apoio da filha de ambos. A referência abre espaço para uma nova linha de sugestões: tal como Trásea foi o sucessor natural do sogro, cujo cognomen adoptou em eloquente homenagem, tal como Árria segue o exemplo de sua mãe, assim Fânia, a filha de ambos, e seu marido Helvídio Prisco darão continuidade à linhagem de figuras da oposição estóica e ambos pagarão por isso, ela com o exílio, ele com a vida. Toda essa espiral de violência, que se estendeu até ao principado de Domiciano, conhecia-a Tácito e a ela alude no Agricola e nas Historiae.

O capítulo 35 descreve o fim de Trásea, em três momentos marcados por tum, dehinc, post. Ele avança para o pórtico onde vem ao seu encontro o questor encarregado de lhe entregar o senatusconsultum que determina a sua morte, sentença que ele já conhecia por um dos seus amigos que viera relatar-lhe o que se passara no senado $(34,1)$. Aí, o sapiens, em vez de temer a morte, em vez de recear o desconhecido, o que seria indigno e contrário à doutrina que o ensinara a ficar impassível perante a dor e a adversidade, deixa-se tomar por um outro sentimento, uma quase alegria por saber que Helvídio, o genro, apenas fora expulso da Italia. De novo emerge a preocupação com os outros, o genro que não morrerá, pelo menos naquela ocasião, mas também a mulher e a filha, receio agora transformado em júbilo porque a crueldade não desferiu um golpe tão violento quanto ele esperava. 
Em seguida, Trásea entra ${ }^{31}$ no seu quarto acompanhado de Helvídio e Demétrio, o herdeiro e sucessor, o filósofo e amigo. Estendeu os pulsos, as veias são-lhe cortadas. Quando o sangue correu, aspergiu com ele a terra e, chamando para perto de si o questor, presente por dever da função, diz-lhe: Libamus Ioui Liberatori. Tal como Sócrates, que fez libações aos deuses com a cicuta que em seguida bebeu ${ }^{32}$, tal como Séneca, que aspergiu os escravos que o rodeavam com a água quente em que pediu que o mergulhassem para facilitar o fluxo do sangue, que teimava em não correr das veias ressequidas pela idade e pela austeridade dos costumes (XV 64, 4), é a Júpiter Libertador que Trásea faz uma libação, com o seu próprio sangue, Júpiter que o liberta da tirania e que ele homenageia no fim de uma vida em que, como era próprio dos estóicos, recusara a pior servidão, aquela que não provém do nascimento mas da submissão a outrem ou aos uitia. Trásea não se submeteu a Nero nem abdicou dos seus princípios para conservar a vida.

Por fim, interpela o questor: Specta, iuuenis... Ele tem consciência de que é, mais do que nunca a partir daquele momento, um modelo de constantia que servirá para aumentar a firmitas animi daqueles que continuarão a viver os tempos em que Nero impõe a sua lei. Ele sabe, como Séneca, que "somente a morte pronunciará sobre nós o juízo definitivo"33. Àquele jovem, que cumpre ordens e verifica a execução de uma pena injusta e arbitrária, Trásea dá o melhor de si: o seu exemplo de coragem e coerência. Mas, falando-lhe, é a todos os seus contemporâneos e aos vindouros que se dirige.

Depois, porque a morte chegava lentamente e sofria dores terríveis, obuersis in Demetrium... Quase diríamos que este fim abrupto, tenha ele sido motivado pela morte de Tácito ou, como parece mais provável, pela perda dos restantes livros, assume uma carga simbólica fortíssima: a vida interrompida brutalmente, a violência que agride e mata os inocentes, a tortura dos homens que pautaram o comportamento pela uirtus a par da recompensa dos que a traíram e desprezaram ${ }^{34}$. Este é de facto um quadro cheio da luz e sombra em que a prosa de Tácito é exímia: a luz da

31 Note-se o uso do presente do indicativo em reperitur e inducit: Tácito põe a cena diante dos olhos dos leitores.

32

Platão, Fédon 117 b.

33 Ep. 26, 6. A tradução é de J. A. Segurado e Campos (Lisboa, F. C. Gulbenkian, 1991).

34 Veja-se o efeito conseguido, em XVI 33, pelo contraste entre as pesadíssimas penas impostas a Trásea, Sorano e a filha, e todos os que com eles foram arrastados no infortúnio, e as enormes recompensas monetárias e honoríficas atribuídas accusatoribus, aos agentes da desgraça de tão nobres figuras. 
coragem e a sombra da cobardia, a claridade da honra e a escuridão do opróbrio, o brilho da morte que liberta e as trevas da vida que se avilta. Trásea, e Séneca, e Bárea, e Servília, e outros como eles, ficam numa zona de luz, tanto mais fulgurante quanto Tácito os desenha como figuras trágicas nos momentos derradeiros, e, no caso dos três estóicos, porque aqui e além os revelou humanos num percurso que nem sempre aceitou, na caminhada, que nem sempre compreendeu, da conquista da uirtus. E, num crescendo que vai deixando transparecer uma progressiva admiração por este e outros modelos de constância e coragem na oposição frontal à prepotência, Tácito propõe à nossa reflexão o sentido da existência de quem não verga ao medo nem à morte, de quem aceita o fim como aceitou a vida, de quem encara a morte como se saúda o dia que desponta.

\section{ANEXO}

\section{Annales XVI 21}

1. Trucidatis tot insignibus uiris, ad postremum Nero uirtutem ipsam exscindere concupiuit, interfecto Thrasea Paeto et Barea Sorano, olim utrisque infensus, et accedentibus causis in Thraseam, quod senatu egressus est cum de Agrippina referretur, ut memoraui, quodque Iuuenalium ludicro parum spectabilem operam praebuerat; eaque offensio altius penetrabat, quia idem Thrasea Pataui, unde ortus erat, ludis cetastis a Troiano Antenore institutis, habitu tragico cecinerat; 2. die quoque quo praetor Antistius ob probra in Neronem composita ad mortem damnabatur, mitiora censuit obtinuitque; et, cum deum honores Poppaeae decernuntur, sponte absens, funeri non interfuerat. 3. Quae oblitterari non sinebat Capito Cossutianus, praeter animum ad flagitia praecipitem, iniquus Thraseae, quod auctoritate eius concidisset, iuuantis Cilicum legatos, dum Capitonem repetundarum interrogant.

\section{Annales XVI 34}

1. Tum ad Thraseam in hortis agentem quaestor consulis missus, uesperascente iam die. Inlustrium uirorum feminarumque coetus frequentes egerat, maxime intentus Demetrio, Cynicae institutionis doctori, cum quo, ut coniectare erat intentione uultus et auditis, si qua clarius proloquebantur, de natura animae et dissociatione spiritus corporisque inquirebat, donec aduenit Domitius Caecilianus, ex intimis amicis, et ei quid senatus censuisset exposuit. 2. Igitur, flentes queritantesque qui aderant, facessere propere Thrasea neu pericula sua miscere cum sorte damnati hortatur, Arriamque, temptantem mariti suprema et exemplum Arriae matris sequi, monet retinere uitam filiaeque communi subsidium unicum non adimere. 


\section{Annales XVI 35}

1. Tum, progressus in porticum, illic a quaestore reperitur, laetitiae propior, quia Heluidium, generum suum, Italia tantum arceri cognouerat. Accepto dehinc senatus consulto, Heluidium et Demetrium in cubiculum inducit; porrectisque utriusque brachii uenis, postquam cruorem effudit, humum super spargens, propius uocato quaestore "Libamus", inquit, "Ioui Liberatori. Specta, iuuenis, - et omen quidem dii prohibeant! ceterum in ea tempora natus es quibus firmare animum expediat constantibus exemplis." 2. Post lentitudine exitus graues cruciatus adferente, obuersis in Demetrium.. 


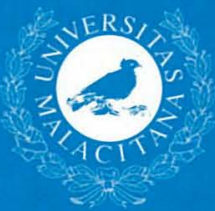

